\title{
Donnan Dialysis Removal of Nitrate from Water: Effects of Process Parameters
}

\author{
Thouraya Turki*, Raghda Hamdi, Mohamed Tlili, Mohamed Ben Amor \\ Laboratory of Natural Water Treatment, Centre of Water Researches and Technologies, Borj Cedria Science \\ and Technology Park, Soliman, Tunisia \\ Email: "thouraya.turki@yahoo.fr
}

Received 21 October 2014; accepted 19 May 2015; published 21 May 2015

Copyright (C) 2015 by authors and Scientific Research Publishing Inc.

This work is licensed under the Creative Commons Attribution International License (CC BY).

http://creativecommons.org/licenses/by/4.0/

c) (i) Open Access

\begin{abstract}
Excess or lack of levels of nitrate in drinking water is harmful to the human health, the concentration of $\mathrm{NO}_{3}^{-}$ions must be maintained at $50 \mathrm{mg} / \mathrm{l}$. Donnan dialysis (DD) used as a driving force of the concentration gradient is an effective and simple technique for nitrate removal. In this paper, the transport of nitrate through an AMX anion-exchange membrane has been studied as a function of driving ion nature, receiver phase concentration, flow rate, temperature and agitation rate under Donnan dialysis condition. It was observed that the hydrodynamic conditions and temperature were the main variables affecting the transmembrane flow. As the driving ion, the chloride ion is more efficient than the hydrogeneocarbonate ion. The systematic study of the different parameters involved showed that the nitrate removal efficiency obtained with a feed synthetic nitrate solution (62 ppm) was off $96 \%$. This efficiency slightly decreases for a tap water containing the same nitrate concentration; it was about $84 \%$. This can be attributed to the complex ionic composition of the natural water.
\end{abstract}

\section{Keywords}

Nitrate, Natural Water, Donnan Dialysis, Anion Exchange Membrane

\section{Introduction}

Nitrate is mainly found in most of natural waters at moderate concentrations but is often enriched to over the contaminant levels from the excessive using of fertilizers and uncontrolled discharge of raw [1]-[3]. Excess nitrate in water supplies can cause eutrophication, which comprises an abundance of aquatic plants, growth of al-

"Corresponding author.

How to cite this paper: Turki, T., Hamdi, R., Tlili, M. and Ben Amor, M. (2015) Donnan Dialysis Removal of Nitrate from Water: Effects of Process Parameters. American Journal of Analytical Chemistry, 6, 569-576.

http://dx.doi.org/10.4236/ajac.2015.66055 
gae, and depletion of dissolved oxygen in water [4]. Furthermore, the presence of nitrate ions in drinking water is a potential public health hazard and can cause infant methemoglobinemia, "blue baby" syndrome [5].

In order to protect public health from the adverse effects of high nitrate intake, Word Health Organisation (WHO) set the standard as $50 \mathrm{mg} / \mathrm{l}$ to regulate the nitrate concentration in drinking water [6].

To remove nitrate from water, several techniques are available: biological [7]-[11]; chemical [12] and physico-chemical such as donnan dialysis [13], electrodialysis [14]-[18], electrodeionization [19], reverse osmosis [20] [21] and ion exchange [22]-[24].

Reverse osmosis and electrodialysis have better economics, larger automation possibilities, lower level in feed and process parameters control and no need for extensive post treatment [25] [26]. However, the utility of these processes has been limited as they are relatively expensive and merely displace nitrate into centrated waste brine that may pose a disposal problem [27].

Donnan dialysis is a simple and one of the most economic membrane processes. The driving force of the process is the chemical potential gradient of components of two solutions separated by a membrane. During donnan dialysis there is a stoichiometric exchange of ions of the same charge (so called counter-ions) through an ion-exchange membrane, and the process ends when donnan equilibrium is reached. The main advantage of this process is that it is economical, simple and especially energy-saving [28]. In spite of these advantages, the process is not yet applied in the industry.

The studies which use donnan dialysis (DD) as separation process to remove nitrate ions are rare. Therefore, the objective of this work is to eliminate nitrate from water by using anion-exchange membrane. To achieve this purpose, the DD is applied for the nitrate removal from a feed synthetic nitrate solution $(62 \mathrm{mg} / \mathrm{l})$ and from a tap water containing the same nitrate concentration.

The effect of the counter-ion, the chloride concentration in the receiver compartment, the flow of circulation of the solution, the agitation rate and the temperature were investigated.

\section{Experimental}

\subsection{Materials}

All chemicals were reagent grade, purchased from Aldrich and their solutions were prepared without further purification with distilled water.

AMX anion exchanges membrane, obtained from Japanese firm, which was kindly provided by Eurodia, has quaternary ammonium as a functional group. The ion-exchange capacity, water content and thickness of the membrane are $1.3 \mathrm{mmol} / \mathrm{g}, 26.1 \%$ and $0.14 \mathrm{~mm}$, respectively.

\subsection{Donnan Dialysis Experiments}

For denitration a cell of dialysis of filter-press type was used. The experimental device is presented in Figure 1. The dialyses cell is built from a bar of polymethacrylate, what allows to have a chemical and electric slowness. The cell includes two compartments assembled between them by intermediate of thread stalks. Both blocks link by the adjustment of a male part in another female. The anionic membrane inserted in the middle assures the waterproofness between both compartments. Hats situated in the extremities contain a boring in which comes to find accommodation a magnetic stirrer of shape studs. This one is trained by a rotating magnetic field generated outside of the cell by blocks of excitement. A peristaltic pump provided with two heads assure the traffic of the fluids in both central compartments. Therafter, we note feed compartment, the one containing the solution to be treated (nitrate solution) and receiver the one containing the solution which is going to exchange its anions with nitrates $\left(\mathrm{NaCl}\right.$ or $\mathrm{NaHCO}_{3}$ solution).

\subsection{Analytical Method of Anions Concentration Measurement}

The concentrations in nitrates at the exit of the receiver and in chloride (or hydrogenocarbonate) at the exit of the feed are then measured. Nitrates are measured according to Rodier protocol [29]. The nitrate concentration in the drinking water is always comprised between $10^{-4}$ and $10^{-3} \mathrm{M}$. However it is possible to find waters particularly charged with a concentration which can be superior to $10^{-3} \mathrm{M}$. This brings us to study a concentration of $10^{-3} \mathrm{M}$. 


\section{Results and Discussions}

\subsection{Effect of the Driving Ion}

The counter ion $\mathrm{X}^{-}$used for nitrate removal from drinking water has to facilitate and favor the extraction of nitrates. For the good progress of the Donnan dialysis, it is necessary to choose against ions so as to minimize associations between these last ones and the fixed sites of the membrane. Indeed, the nitrate removal efficiency depends on the nature of the ions used to make the extraction. It's better to use monovalent ions because they can move easily through the membrane better than the bivalent which can interact with the fixed sites [30]-[33]. For this reason we proceeded to study two against monovalents ions $\left(\mathrm{Cl}^{-}\right.$and $\left.\mathrm{HCO}_{3}^{-}\right)$.

To be able to choose the most adequate driving ion in our study, we realized various dialyses by changing every time the nature of the counter-ion $\mathrm{X}^{-}$in the receiver solution with $\mathrm{X}^{-}=\mathrm{Cl}^{-}$or $\mathrm{HCO}_{3}^{-}$. The results of the realized dialysis are represented on the Figure 2.

By comparing the curves of the Figure 2, we can conclude that chloride should be chosen as the driving ion for the transport of nitrate. This finding in the present study agreed well with the reported literature [34].

\subsection{Effect of the Chloride Concentration in the Receiver Solution}

In the receiver compartment, the efficiency of the transfer is conditioned by the ionic activity of chlorides and

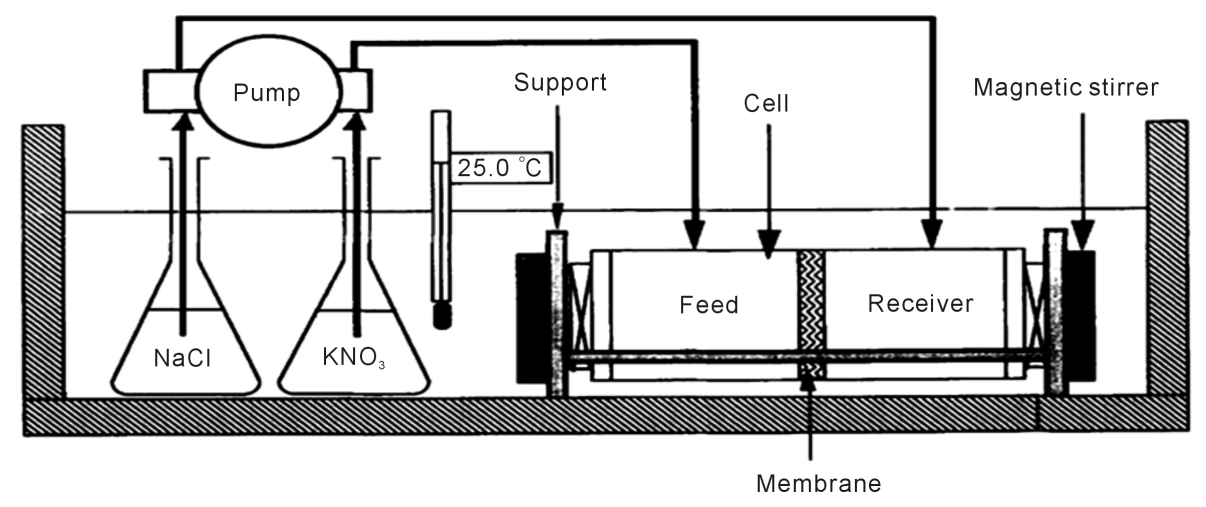

Figure 1. Shematic set-up of the Donnan dialysis apparatus used in our study.

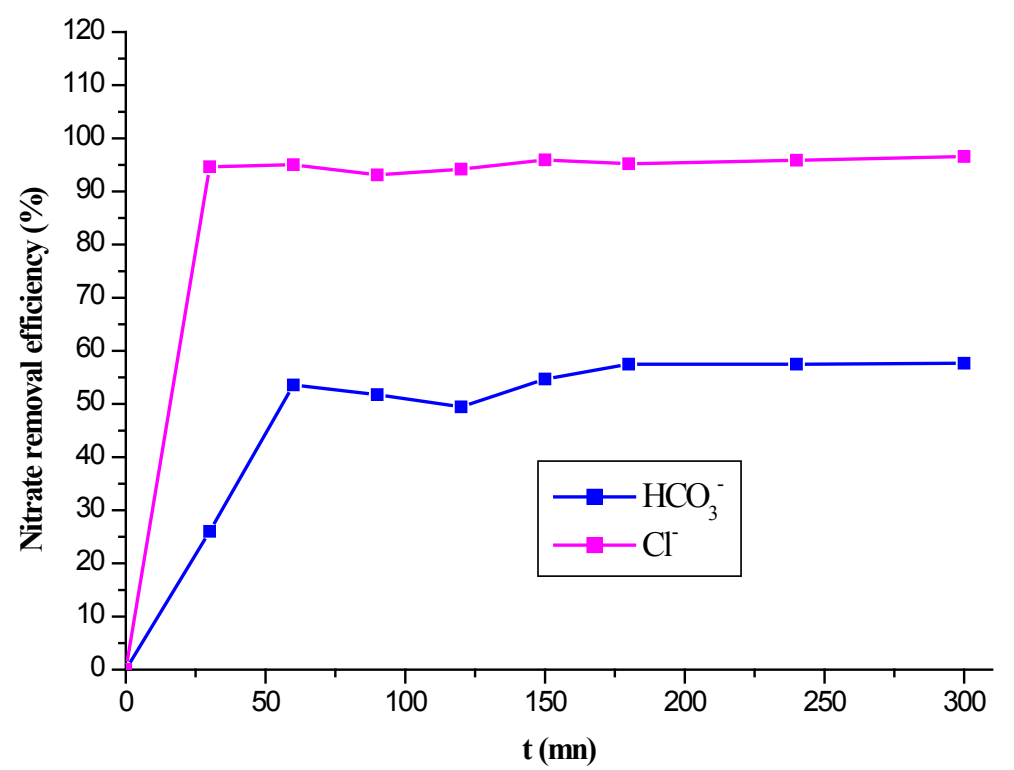

Figure 2. The effect of different driving ions on the removal of nitrate (feed phase: $10^{-3} \mathrm{M}$ $\mathrm{NO}_{3}^{-}$). 
their concentrations. This parameter must be optimized thus carefully. For this study, we maintained constant the concentration of the feed solution $\left(10^{-3} \mathrm{M}\right.$ in $\left.\mathrm{NO}_{3}^{-}\right)$and we varied that of receiver solution containing $\mathrm{Cl}^{-}$in the range of $(0.01 \mathrm{M}-0.5 \mathrm{M})$. The obtained results are represented on the Figure 3 .

By examining this curves, we notice that the kinetics of the four curves are very fast during the first hour to stabilize later. We can conclude also that the increase of the concentration of $\mathrm{Cl}^{-}$in the receiver allows increasing the return on elimination of nitrates. Then the denitratation is more successful by using $\left[\mathrm{Cl}^{-}\right]=0.5 \mathrm{M}$ in the receiver solution. This result is in agreement with that reported by Dieye [35] who, to see the influence of the concentration in the receiver, fix that of the feed and made essays of dialysis for various concentrations in the receiver. He noted that the increase of the amount of the counter-ion in the receiver allows increasing strikingly the quantity transferred from a compartment to the other one. It will be thus preferable in practice to work with the highest possible chloride concentration in the receiver compartment.

\subsection{Influence of the Flow of Circulation of the Solutions}

The flow of circulation translates the residence time of the solutions in every compartment, thus their time of contact with the membrane. To bring to light its influence on the return on elimination of nitrates, we varied the flow of circulation of the fluids (Q) from 180 to $450 \mathrm{ml} \cdot \mathrm{h}^{-1}$ with a concentration of $10^{-3} \mathrm{M}$ in nitrates in the feed compartment and $0.5 \mathrm{M}$ of chloride in the receiver solution.

The essays presented on the Figure 4 were realized with the membrane AMX while adjusting the excitement to its maximal value in both compartments.

According to these curves, we note that the kinetics of transfer are important during the first hour of the experience, then it stabilizes gradually until reach the state of balance. The return on elimination of the nitrates decreases with the increase of the flow of circulation of the solutions.

\subsection{Effect of the Temperature}

As shown in Figure 5, the removal of the nitrates ions decreases as a function of the temperature. In fact, the nitrate removal efficiency is off $98 \%$ at $25^{\circ} \mathrm{C}$ but it decrease to $35 \%$ at $35^{\circ} \mathrm{C}$. we can conclude that the AMX anion exchange membrane is more efficient at low temperature.

\subsection{Effect of the Agitation Rate}

To study the influence of the agitation rate, we have realist ionic dialysis with membrane AMX, a solution of

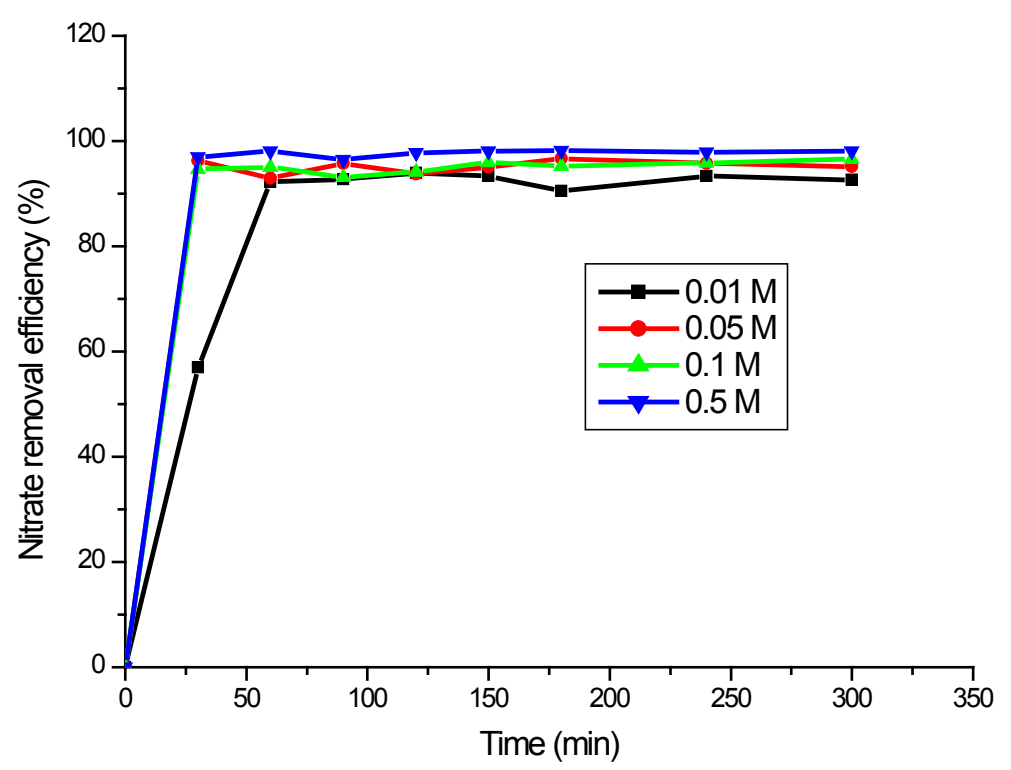

Figure 3. Time dependence of nitrate removal efficiency for different concentrations of receiver solution (feed phase: $10^{-3} \mathrm{M} \mathrm{NO}_{3}^{-}$). 


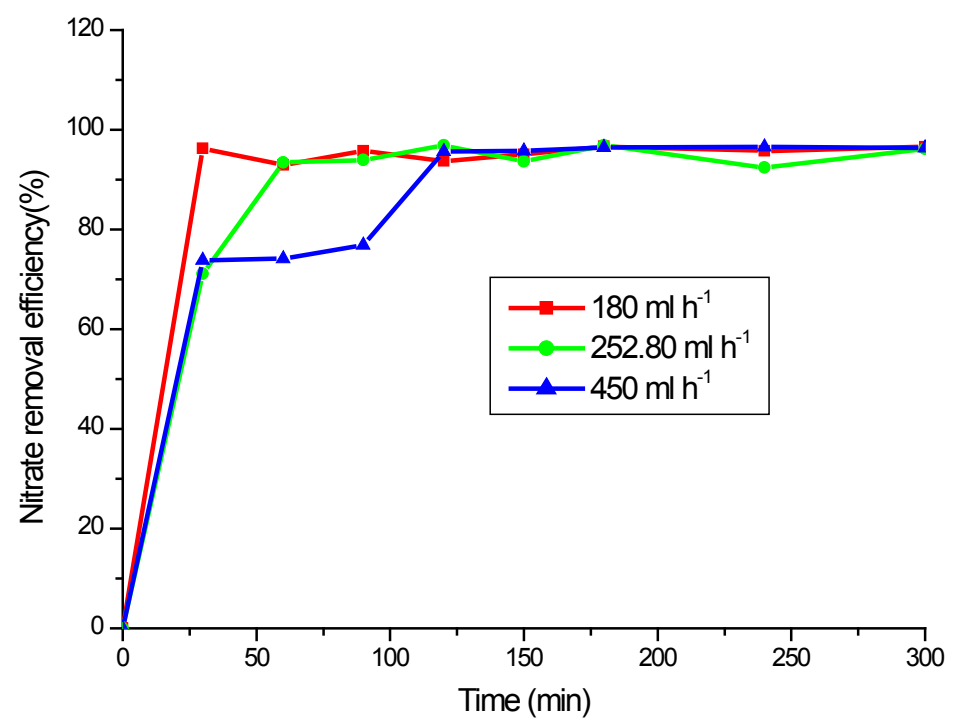

Figure 4. Time dependence of nitrate removal efficiency for different flow rate (feed phase: $10^{-3} \mathrm{M} \mathrm{NO}_{3}^{-}$, receiver phase: $0.5 \mathrm{M} \mathrm{Cl}^{-}$).

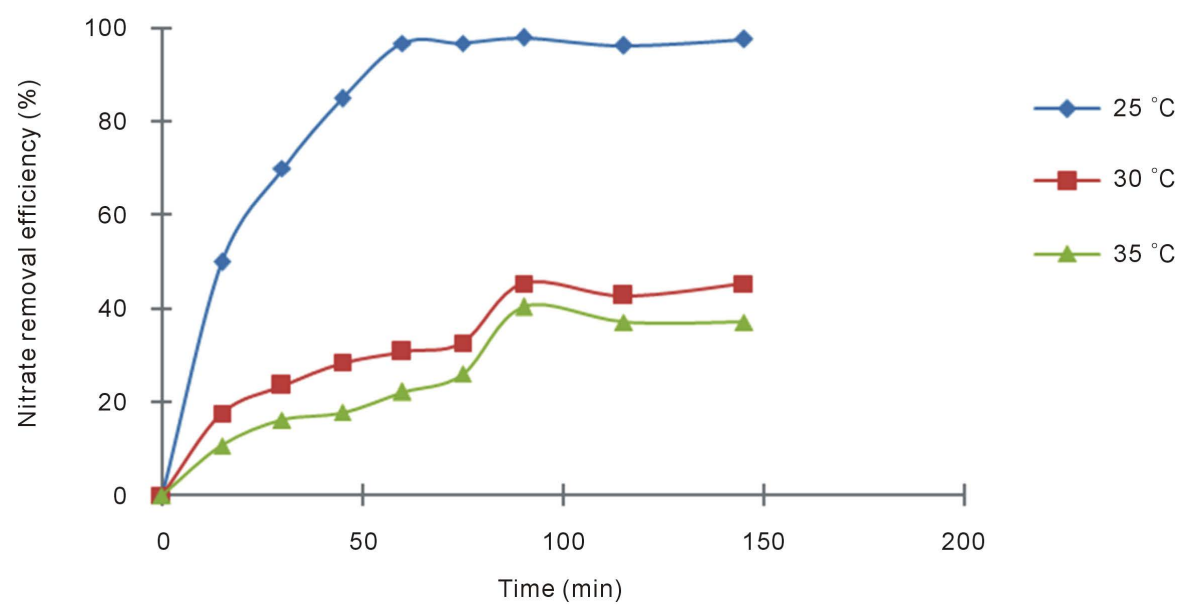

Figure 5. Variation of the nitrate removal efficiency of the AMX membrane as a function of the temperature for a flow of circulation of solutions of $180 \mathrm{ml} \cdot \mathrm{h}^{-1},\left[\mathrm{NO}_{3}^{-}\right]=10^{-3} \mathrm{M} ;\left[\mathrm{Cl}^{-}\right]=$ $0.5 \mathrm{M}$.

$\mathrm{KNO}_{3} 10^{-3} \mathrm{M}$ in the food and a solution $\mathrm{NaCl} 0.5 \mathrm{M}$ in the receiver. The flow of circulation of the solutions in the two compartments is fixed at $180 \mathrm{ml} \cdot \mathrm{h}^{-1}$.

Figure 6 shows that the nitrate removal efficiency increases with the stirring velocity. The transfer is obtained with a maximum agitation. This variation can be due to the reduction in the boundary layers of diffusion which can have a major influence on the transfer of the ions in the two compartments.

\subsection{Nitrate Removal from Synthetic Water by Donnan Dialysis}

Having to determine the optimal parameters for nitrate removal by Donnan dialysis study, we proceed to eliminate by this technique the nitrates of synthetic water possessing the same composition as that of a tap water but we changed the content in nitrate for which exceed the standards and of another synthetic solution which contains only the nitrates ion of $10^{-3} \mathrm{M}$. We realized this study by following the optimal conditions deducted from studies carried in the previous part $\left(\left[\mathrm{NO}_{3}^{-}\right]=10^{-3} \mathrm{M} ;\left[\mathrm{Cl}^{-}\right]=0.5 \mathrm{M} ; \mathrm{T}=25^{\circ} \mathrm{C} ; \mathrm{Q}=180 \mathrm{ml} \cdot \mathrm{h}^{-1}\right)$. The nitrate removal efficiency is summarized in Table 1. 


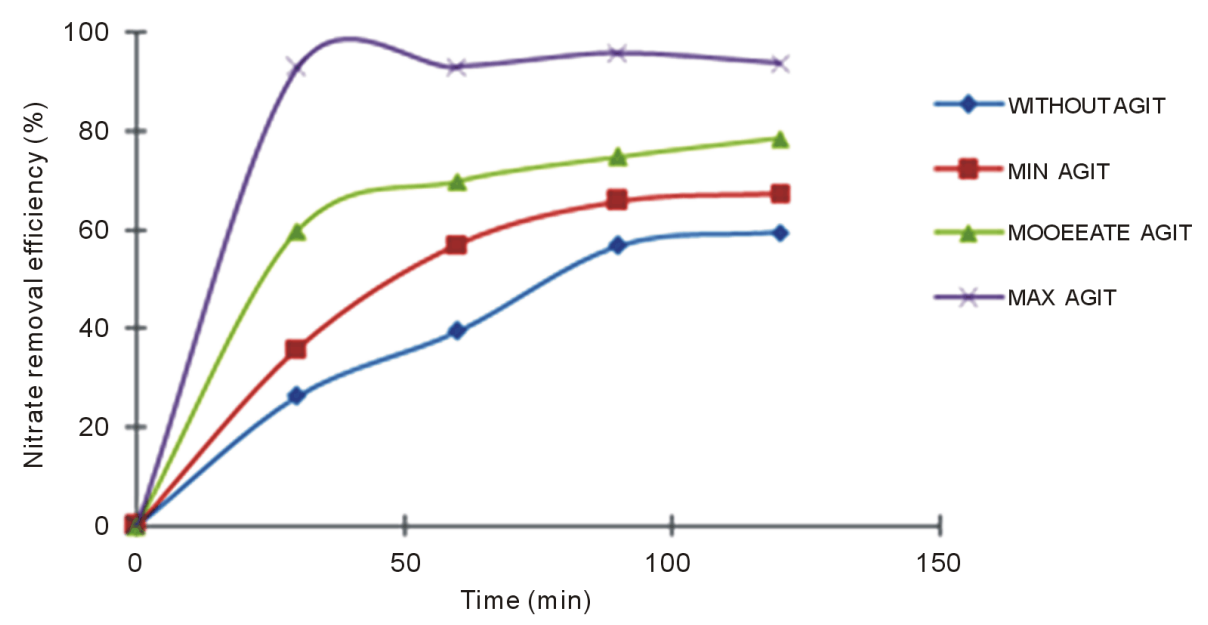

Figure 6. Variation of the nitrate removal efficiency of the AMX membrane as a function of the agitation.

Table 1. Nitrate removal efficiency of the two tested synthetic solutions.

\begin{tabular}{ccc}
\hline Essays & $\begin{array}{c}\text { Removal efficiency (\%) } \\
\text { (synthetic tap water) }\end{array}$ & $\begin{array}{c}\text { Removal efficiency (\%) } \\
\text { (nitrates solution) }\end{array}$ \\
\hline 1 & 85.65 & 96.53 \\
2 & 83.89 & 95.87 \\
3 & 86.13 & 96.11 \\
*Removal efficiency (\%) & 85.22 & 96.17 \\
\hline
\end{tabular}

${ }^{*}$ The average of the three replicated experiments.

The obtained results in the Table 1 indicate that in the optimal conditions, the return on elimination of nitrates of the synthetic solution of the tap water is considered as mattering because it exceeds $84 \%$. But this value remains less important by comparing it with the value of the return obtained with the solution which contains only the nitrates ions and which exceeds $96 \%$. This profit can be explained by the influence of the presence of the other anions $\left(\mathrm{Cl}^{-}, \mathrm{SO}_{4}^{2-}, \mathrm{HCO}_{3}^{-}\right)$in the tap water who prevent the passage of the nitrates ions through the anion exchange membrane first of all, what reduces the return on the Donnan dialysis.

\section{Conclusion}

Donnan dialysis is a simple and one of the most economic membrane processes. The driving force of the process is the chemical potential gradient of components of two solutions separated by a membrane. During Donnan dialysis there is a stochiometric exchange of ions of the same charge (so called counter-ions) through an ionexchange membrane, and the process ends when Donnan equilibrium is reached. An important field of Donnan dialysis application is undesired ions removal from water. The experiments performed in this work show that the hydrodynamic conditions and temperature are the main variables affecting the transmembrane flow. In fact, the nitrate removal efficiency increases with the stirring velocity and is about $98 \%$ at $25^{\circ} \mathrm{C}$.

\section{References}

[1] Peavy, H.S., Rowe, D.R. and Tchobanoglous, G. (1985) Environmental Engineering. McGraw-Hill Book Company, New York, 696.

[2] Lin, S.H. and Wu, C.L. (1996) Removal of Nitrogenous Compounds from Aqueous Solution by Ozonation and Ion Exchange. Water Research, 30, 1851-1857. http://dx.doi.org/10.1016/0043-1354(95)00329-0

[3] Sihrimali, M. and Singh, K.P. (2001) New Methods of Nitrate Removal from Water. Environmental Pollution, 112, 351-359. http://dx.doi.org/10.1016/S0269-7491(00)00147-0 
[4] Tchobanoglous, G. (1979) Waste Water Engineering: Treatment Disposal Reuse. 2nd Edition, McGraw-Hill, New York.

[5] Knobeloch, L., Salna, B., Hogan, A., Postle, J. and Anderson, H. (2000) Blue Babies and Nitrate-Contaminated Well Water. Environmental Health Perspectives, 108, 675. http://dx.doi.org/10.1289/ehp.00108675

[6] WHO (2001) Guidelines for Drinking-Water Quality. Fluoride, World Health Organization. http://www.who.int/water-sanitation-1th/GDWQ/chemicals/fluoridefull/html

[7] Wasik, E., Bohdziewicz, J. and Blasszezyk, M. (2001) Removal of Nitrates from Ground Water by a Hybrid Process of Biological Denitrification and Microfiltration Membrane. Process Biochemistry, 37, 57-64. http://dx.doi.org/10.1016/S0032-9592(01)00177-7

[8] Dawson, R.N. and Murphy, K.L. (1972) Factors Affecting Biological Denitrification of Waste Water. Advances in Water Pollution Research. In: Jenkins, S.H., Ed., Proceedings of the 6th International Conference, Jerusalem, Pergamon Press, Oxford, 671-683.

[9] Gros, H. and Ginnocchio, J.C. (1983) Nitrate Removal from Groundwater by Autotrophic Microorganisms. Water Supply, 4, 11-21.

[10] Van der Hoek, J.P. (1987) Nitrate Removal from Ground Water. Environment Technology, 593-603. http://dx.doi.org/10.1007/978-94-009-3663-8_72

[11] Deguin, A. (1982) Elimination des nitrates par échanges d'ions. Procédé Dénitrasaur, Eau Ind. Nuis., 69, 39-44.

[12] Gunderloy Jr., F.D. and Wagner, R.I. (1970) Environmental Pollution Agency.

[13] Wisniewska, G. and Winnicki, T. (1985) Removal of Nitrate Ions Acidic Wastewater by Donnan Dialysis Involving Tabular Exchange Membranes. Desalination, 56,161-173. http://dx.doi.org/10.1016/0011-9164(85)85023-2

[14] Rautenbach, R., Kopp, W., HeUekes, R., Peters, R. and Gan, V. (1986) Separation of Nitrate from Well Water by Membrane Processes (RO/ER). Aqua, 5, 279-282.

[15] Rautenbach, R. and Kopp, W. (1987) Nitrate Reduction of Well Water by Reverse Osmosis and Electrodialysis-Studies on Plant Performance and Costs. Desalination, 65, 241-258. http://dx.doi.org/10.1016/0011-9164(87)90137-8

[16] Kneifel, K. and Ltihrs, G. (1988) Nitrate Removal by Electrodialysis for Brewing Water. Desalination, 68, $203-209$. http://dx.doi.org/10.1016/0011-9164(88)80055-9

[17] Schoeman, J.J., Buys, I.J.M., Schute, I.B. and Macleod, H. (1988) Pilot Investigation on the Treatment of Fertilizer Manufacturing Process Effluent Using Lime and Electrodialysis Reversal. Desalination, 70, 407-429. http://dx.doi.org/10.1016/0011-9164(88)85070-7

[18] Indusekhar, V.K., Trivedi, G.S. and Shah, B.G. (1991) Removal of Nitrate by Electrodialysis. Desalination, 84, 213221. http://dx.doi.org/10.1016/0011-9164(91)85131-D

[19] Ganzi, G.C., Giuffrida, A.J. and Stone, T.E. (1990) ICOM'90, Chicago, 2, 861.

[20] Bailey, D.A. and Jones, K. (1974) The Reclamation of Water from Sewage Effluents by Reverse Osmosis. Inst. W.P.C., 73, 353-364.

[21] Allard, J.J. (1974) Reverse Osmosis. Technical University Munich, 69, 49.

[22] Korngold, E. (1973) Removal of Nitrates from Potable Water by Ion Exchange. Water, Air and Soil Pollution, 1, 15. http://dx.doi.org/10.1007/BF00572386

[23] Dore, M. (1986) Removal of Nitrate in Drinking Water by Ion Exchange-Impact on the Chemical Quality of Treated Water. Water Research, 20, 221-232. http://dx.doi.org/10.1016/0043-1354(86)90012-6

[24] Cox, M., Murgatroyd, D., Gammage, A. and Wilkinson, D. (1987) Recent Developments in Ion Exchange. In: Williams, P.A. and Hudson, M.J., Eds., International Conference on Ion Exchange Processes, Elsevier Applied Science, London.

[25] Schoeman, J.J. and Steyn, A. (2003) Nitrate Removal with Reverse Osmosis in a Rural Area in South Africa. Desalination, 155, 15-26. http://dx.doi.org/10.1016/S0011-9164(03)00235-2

[26] El Midaoui, A., Elhaninouni, F., Taky, M., Chay, L., Sahli, M.A.M., Echihabi, L. and Hafsi, M. (2002) Optimization of Nitrate Removal Operation from Ground Water by Electrodialysis. Separation and Purification Technology, 29, 235244. http://dx.doi.org/10.1016/S1383-5866(02)00092-8

[27] Wasik, E., Bohdziewicz, J. and Blasszezyk, M. (2001) Removal of Nitrate Ions from Natural Water Using a Membrane Bioreactor. Separation and Purification Technology, 22-23, 383-392. http://dx.doi.org/10.1016/S1383-5866(00)00123-4

[28] Tor, A., Buyukerkek, T., Çenyeloglu, Y. and Ersoz, M. (2004) Simultaneous Recovery of Cr(III) and Cr(VI) from the Aqueous Phase with Ion-Exchange Membranes. Desalination, 171, 233-241.

http://dx.doi.org/10.1016/j.desal.2004.02.106 
[29] Rodier, J. (1996) Water Analysis. 7th Edition, Dunod, Paris. (In French)

[30] Miyoshi, H. (1998) Diffusion Coefficients of Ions through Ion Exchange Membrane in Donnan Dialysis Using Ions of Different Valence. Journal of Membrane Science, 141, 101-110. http://dx.doi.org/10.1016/S0376-7388(97)00297-4

[31] Saracco, G. (1997) Transport Properties of Monovalent-Ion-Permselective Membranes. Chemical Engineering Science, 52, 3019-3031. http://dx.doi.org/10.1016/S0009-2509(97)00107-3

[32] Bouhidel, K.E. and Rumeau, M. (2000) Comparison of the Electrodialytic Properties of $\mathrm{NiSO}_{4}$ and $\mathrm{NiCl}_{2}$ : Influence of the Salt Nature in Electrodialysis. Desalination, 132, 195-197. http://dx.doi.org/10.1016/S0011-9164(00)00149-1

[33] Gartner, R.S., Wilhelm, F.G., Witkamp, G.J. and Wessling, M. (2005) Regeneration of Mixed Solvents by Electrodialysis: Selective Removal of Chloride and Sulfate. Journal of Membrane Science, 250, 113-133. http://dx.doi.org/10.1016/j.memsci.2004.10.022

[34] Ergun, E., Tor, A., Cengeloglu, Y. and Kocak, I. (2008) Electrodialytic Removal of Fluoride from Water: Effects of Process Parameters and Accompanying Anions. Separation and Purification Technology, 64, 147-153. http://dx.doi.org/10.1016/j.seppur.2008.09.009

[35] Dieye, A., Larchet, C., Auclair, B. and Mar-Diop, C. (1998) Elimination des fluorures par la dialyse ionique croisée. European Polymer Journal, 34, 67-75. http://dx.doi.org/10.1016/S0014-3057(97)00079-7 